Øyvin Rannem

\title{
Striden om typografiens sjel - Max Bill versus Jan Tschichold
}

\author{
Sammendrag \\ Den korte og følelsesladede debatten mellom den tyske typografen og designeren Jan \\ Tschichold og den sveitsiske arkitekten og designeren Max Bill fra 1946 berører noen \\ sentrale estetiske og funksjonelle aspekter ved typografi og grafisk design. Foranledningen \\ for debatten var at Tschichold $i$ lopet av krigsårene 1940-45 hadde vendt seg mot sine \\ tidligere standpunkter og gått til angrep på funksjonalismen og «den nye typografien». \\ Isteden tok han den tradisjonelle, symmetriske typografien i forsvar og gav den en fornyelse \\ og en kvalitetsheving. Artikkelen tar for seg debatten og kommenterer de ulike standpunktene \\ $i$ lys av den senere faghistorien, og fokuserer spesielt på hvordan ideologi og tidsavhengig \\ tankegods kan påvirke argumenter om funksjonalitet og estetikk.
}

Nøkkelord: Jan Tschichold, Max Bill, Die neue Typographie, typografi, funksjonalisme.

\section{Jan Tschicholds historiske helomvending}

En gang på slutten av året 1945 holdt den tysk-sveitsiske typografen og designeren Jan Tschichold (1902-1974) et foredrag til medlemmer av Verbandes schweizerischer Graphiker under tittelen Konstanter i typografien der han bl.a. sa:

Den nye typografien [Die neue Typographie] er fremdeles ikke blitt avløst [überholt], men den har vist seg ubrukelig til annet enn reklame og aksidens ${ }^{1}$. For boken, og særlig den litterære, er den stort sett fullstendig ubrukelig (Tschichold 2000:71, min oversettelse).

Dette må sies å være et svært overraskende utsagn fra en mann som hadde vært den nye typografiens fremste fanebærer, og som bare noen år tidligere i kompromissløse vendinger og i mange ulike sammenhenger hadde fremhevet og begrunnet denne funksjonalistiske stilen som den eneste logiske og mulige løsningen for et moderne og tidsmessig typografisk design (Se f.eks. Tschichold 1928.) Utsagnet avfødte en kort og følelsesladet debatt i tidsskriftet Schweizer Graphische Mitteilungen i 1946 mellom Tschichold og Max Bill (1908-1994). Sistnevnte var en av de førende skikkelsene i den sveitsisk-nasjonale videreføringen av funk sjonalismen, den såkalte sveitsertypografien. Debatten gjør på mange måter opp status for typografien etter annen verdenskrig, og berører spørsmål som er sentrale i typografi og grafisk design. Men den gir også innsikt i, og forklaring på, en av de mest berømte og konsekvensfylte helomvendinger i typografiens og grafisk designs historie. Christopher Burkes Tschichold-biografi som kom i 2007 (Burke 2007) skapte ny interesse omkring personen og fenomenet Jan Tschichold. Samtidig kom Taro Yamamotos artikkel «Considering the Dispute between Jan Tschichold and Max Bill» (Yamamotos 2007). Med dette som bakgrunn har jeg ønsket å gå tilbake til den opprinnelige debatten og forsøke å se de ulike synspunktene i lys av senere faghistorie.

\section{Die neue Typographie}

Den nye typografien var i mellomkrigstiden først og fremst et tysk fenomen og var i utgangspunktet inspirert av Bauhaus . Den var basert på asymmetrisk komposisjon og en geometrisk oppdeling av flaten. Skriften var grotesk, en skrift uten seriffer og med en tilnærmet monolineær strekstruktur, med andre ord uten overflødig dekor og staffasje. ${ }^{2}$ Hovedpoenget var frigjøringen fra symmetrien og antikvaskriften, som begge ble regnet som en arv fra renessansen. Den ble betraktet som ornamental og unødvendig dekorativ, håpløst upassende $\mathrm{i}$ en moderne verden og distraherende for den moderne leser. Inspirert av kunstnere 
som Piet Mondrian og Vasilij Kandinskij tok de nye typografene flaten i bruk på en ny og utfordrende måte, og de brukte asymmetrien til å skape balanse og sammenheng i teksten. Et nøkkelord som ofte gikk igjen, var klarhet [Klarheit], noe som innebar at der symmetrien med sin bydende aksialitet både inviterte til, og gjorde det mulig med, større nyansering og kompleksitet, krevde den asymmetriske balanse enkelhet og klar struktur. Og der symmetrien arbeidet med harmoniske proporsjoner og kongruente former, var den nye typografien mer dynamisk; den brukte elementene til å gå til angrep på flaten for å skape flatedeling, kontrast og bevegelse. Stilen bærer nok preg av at de toneangivende skikkelsene - Laszlo MoholyNagy, Vasilij Kandinskij, Piet Mondrian og El Lissizkij for å nevne noen - var eller ble arkitekter eller kunstnere innenfor maleri og grafikk. Papirformatene som ble foretrukket, var industristandarden A4 og A5. Asymmetrisk oppstilling av teksten ble dessuten oppfattet som en logisk konsekvens av lesemønsteret - fra venstre mot høyre.

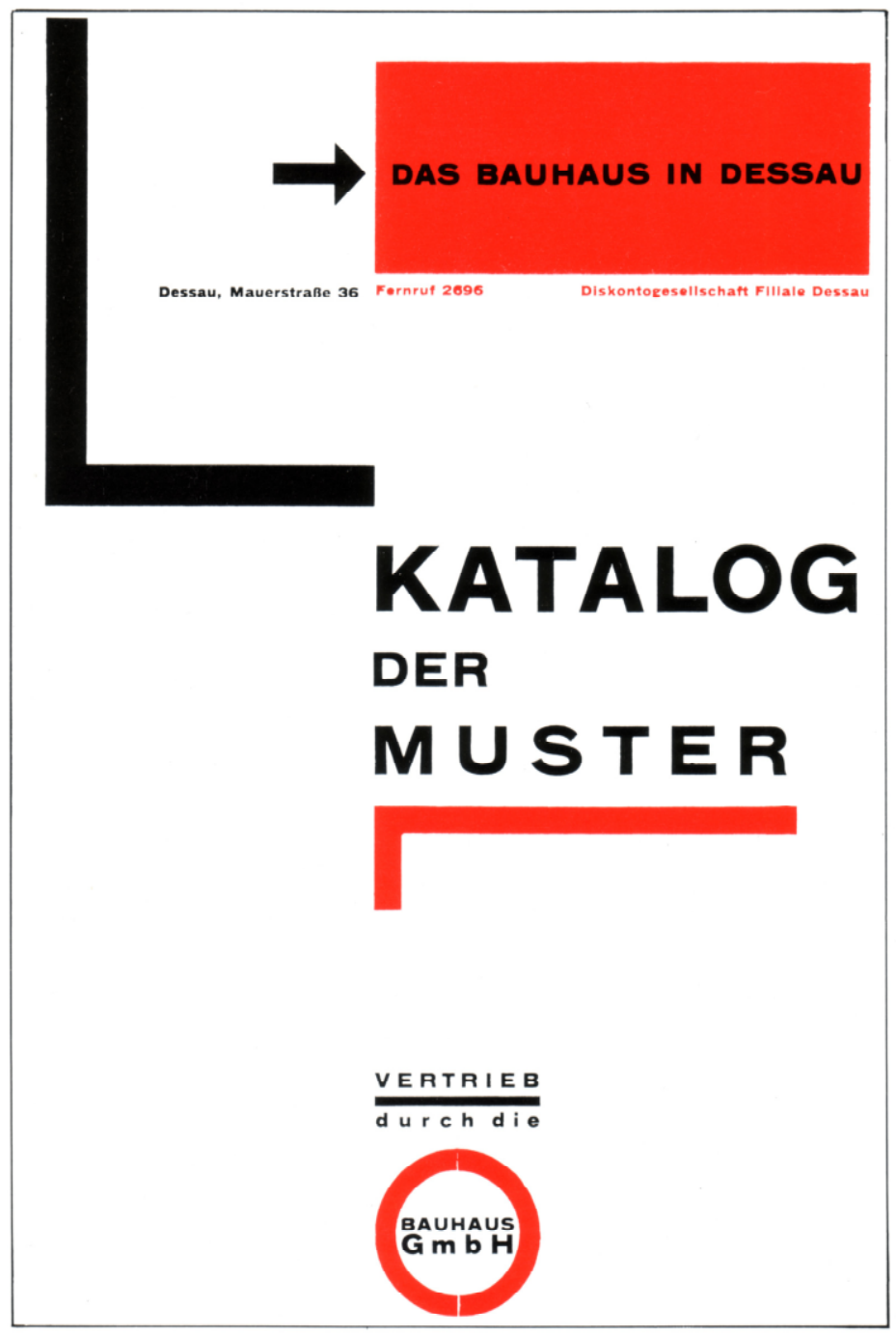

Herbert Bayers omslag til en katalog for Bauhausprodukter (Spencer 1982:146).

En viktig del av det ideologiske grunnlaget i funksjonalismen generelt, var tanken om at funksjonen har en slags naturlig eller naturgitt formfasit: Til en gitt funksjon svarer en eneste riktig eller funksjonell form - en tanke som fikk sitt uttrykk i slagordet form follows function. (Louis Sullivan sit. i Michl 1995.) Det gjelder for formgiveren å forstå funksjonen og deretter finne formen. Funksjonen rettferdiggjør så å si formen - om så på bekostning av estetikken. Stilen spredte seg til en rekke land i Europa, også til Norge (Eng 1998), og øvde innflytelse på 
alle slags trykksaker, men kanskje mest innenfor reklame, noe som for $\emptyset$ vrig er et av Engs poenger. I England, derimot, fikk ikke stilen noe nedslag før etter annen verdenskrig (f.eks. i Kinross 1992:116).

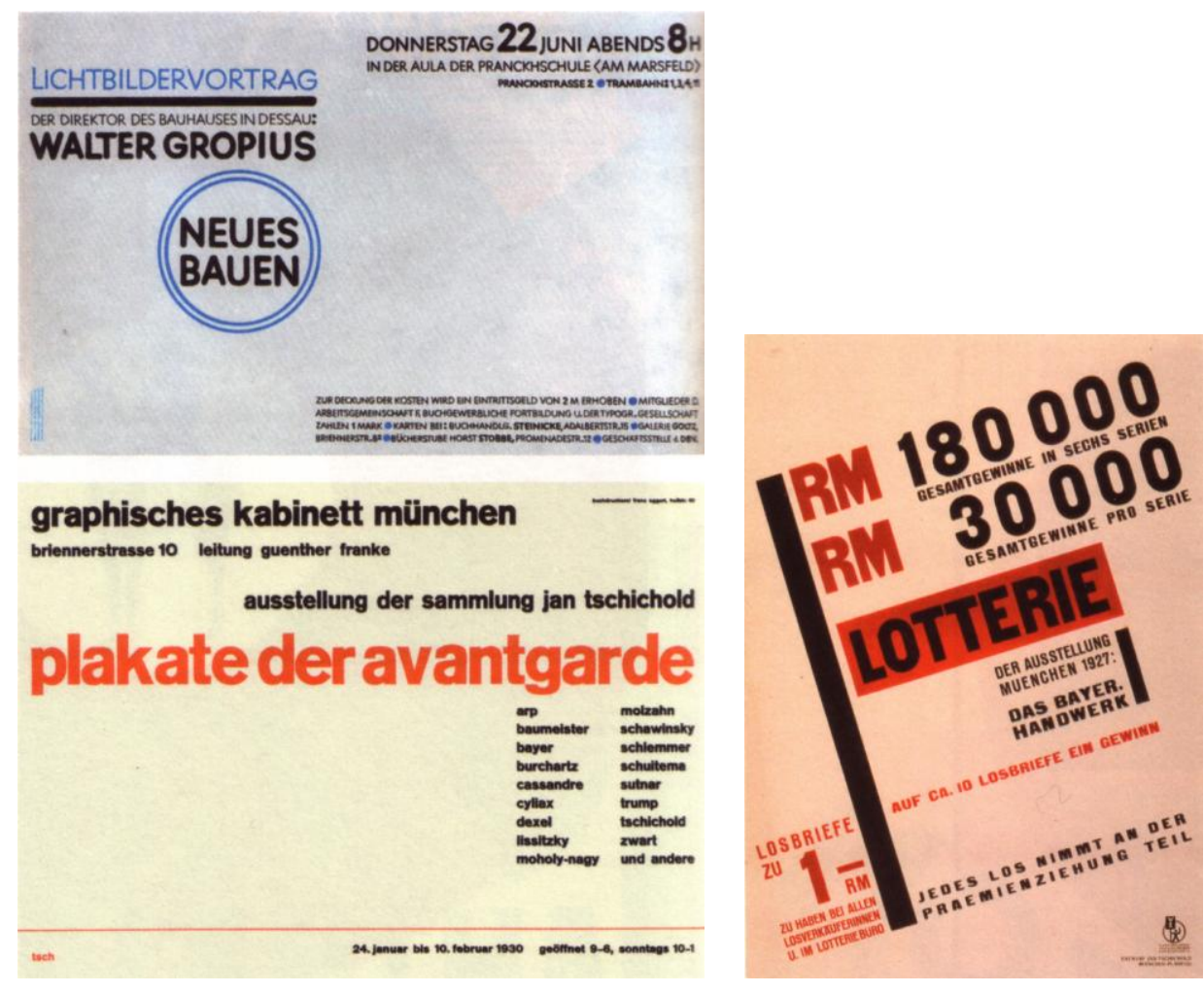

Eksempler på Tschicholds design i den nye stilen. Øverst til venstre en plakat fra 1926 som annonserer en forelesning av Walter Gropius ved Graphische Berufsschule i München. Under, en plakat fra 1930 for en utstilling i Graphisches Kabinett i München. Til høyre, lotteriseddel fra 1927 (Burke 2007:72).

\section{Tschichold og Die neue Typographie}

Jan Tschichold var uten tvil en helt usedvanlig begavelse, som $\emptyset$ vet stor innflytelse på utviklingen av typografi og grafisk design både i mellomkrigstiden og i tiden etter krigen, om enn på fullstendig motsatte måter. Han var opprinnelig tysker med slavisk bakgrunn, og hadde utdannelse som tegnelærer, skrifttegner og kalligraf. I 1923 ble han kraftig vekket og inspirert av Bauhaus. Fra da av og frem til krigens utbrudd arbeidet han utrettelig for å fremme en ny typografisk stil - Die neue Typographie - ikke bare i praksis, men også i teori. Han ble kort og godt den nye typografiens fremste fanebærer.

Men det var også et politisk aspekt ved den nye typografien. Forkjemperne var opprørere og revolusjonære, og ikke bare i faglig forstand. De hørte, nærmest uten unntak, hjemme på den politiske venstresiden. Tschichold kalte seg til og med i en periode Iwan, en åpenlys flørt med nyere, revolusjonær kunst og design i Sovjetstaten (Burke 2007:25). Da Hitler kom til makten, ble den nye typografien stemplet som «Kulturbolschewismus» (Burke 2007:138). Nazistene ønsket en nasjonal typografisk stil basert på gotisk skrift. De nye typografene kom i opposisjon til regimet og fikk problemer med myndighetene, noen av dem fikk tøff behandling. Tschichold selv ble internert i en «forbedringsanstalt», der han satt i halvannet år. Da han kom ut, tok han familien med seg og reiste til S veits, og der ble han til krigens slutt. 


\section{Tschicholds kritikk av Die neue Typographie}

Under oppholdet i Sveits skjedde det noe bemerkelsesverdig. Han fikk jobb som designer i det lille forlaget Benno Schwabe i Basel, og det var i arbeidet med typografisk utforming av bøker at Tschichold oppdaget at den nye typografien kom til kort; den var for nyanseløs og for påtrengende; den kvernet alt inn i en standard form som fremhevet seg selv på bekostning av innholdet.

Dette går, så vidt jeg kan se, hånd i hanske med den britisk-amerikanske typografiteoretikeren Beatrice Wardes berømte metafor The Crystal Goblet fra 1932 der hun sammenligner typografi med et vinglass: «På samme måte som vinglasset må være gjennomsiktig og ikke fremheve seg selv, men la vinen komme til sin rett, må typografien være transparent og ikke komme mellom leseren og innholdet» (Warde 1970:24, min oversettelse). Tschichold sier selv i et essay i Typographische Monatsblätter fra 1946: «Boktypografien må ikke reklamere!» (Burke 2007:294, min oversettelse). I et brev til Paul Renner $^{3}$ i 1948 sier Tschichold at det er bedre at typografien er stilløs enn at den har en stil man ikke tror på. «Et totalt fravær av stil er sannere og mer grunnleggende humant enn en 'posisjon' man ikke tror på» (Burke 2007:295, min oversettelse). Og han har da åpenbart funnet at den enkle, naturlige, upretensiøse og harmoniske symmetrien og de klassiske antikvabokstavene er best egnet til å skape den nødvendige nøytrale ramme for å presentere omfattende tekstlig budskap som skal leses i sammenheng.

Det kan se ut som dette handler om lesemodus: Estetisk lesing kaller Louise Rosenblatt den formen for lesing som skjer for opplevelsens skyld, der leseren så å si forsvinner inn i handlingen - i motsetning til den målrettede, informasjonssøkende lesingen som hun kaller efferent lesing (Rosenblatt sitert i Smith 1994:247.) Det Tschichold ser ut til å ha erkjent, er at lesing av større tekstmengder med et innhold som kan veksle i rytme, modus og følelsenivå, krever en typografi som er mest mulig transparent. Det kan virke som om han selv er overbevist om at typografien han skaper er noytral og objektiv.

Men han går enda lenger, han erklærer at Die neue Typographie - og ikke minst teorien som forklarer og begrunner den - har de samme autoritære, kompromissløse trekkene som nazismen: Den er dogmatisk, den ensretter, og den tåler ikke motforestillinger og debatt. Og som skolens ledende ideolog får han en ekkel følelse av å være «Führer» «Den lederrollen som falt på meg som den eneste spesialisten i gruppen, var i seg selv en 'Führer'-rolle» (Tschichold 2000:74, min oversettelse). I en tale til Type Directors Club i New York i 1959 sier han: «Jeg oppdaget de mest sjokkerende likheter mellom den nye typografiens læresetninger og nasjonalsosialismen og fascismen. [...] de brutale [ruthless] restriksjonene i bruk av skrift, en parallell til Goebbels' beryktede Gleichschaltung, ${ }^{4}$ og den mer eller mindre militaristiske oppstillingen av linjene»(Burke 2007:304, min oversettelse.). Det samme gjelder den rigorøse begrensningen av formatene til A-rekken. Andre steder har han kalt A5formatet uskjønt og uegnet som bokformat (Tschichold 1962:3). «Typographers have to be fussy about details», sier Robin Kinross i sin anmeldelse av Ruari MacLeans biografi om Jan Tschichold fra 1990 (Kinross 2002b:174), og han fortsetter «Jan Tschichold ... was one of the fussiest».

I 1946 ble Tschichold invitert til Penguin Books for å bygge opp en ny typografisk standard for forlagets billigbøker. Han ankom i mars 1947 og ble der i to og et halvt år (McLean 1997:11-13). Alle som har lest Graham Greene og Simenon på engelsk i pocketformat kjenner resultatet: Penguinbøkene fikk en tradisjonell, men raffinert og sober typografisk profil med gjennomført kvalitet ned til minste bokstavmellomrom, og i et format i det klassiske gylne snitt.

Dette var så godt som å gå over til fienden, og må ha blitt oppfattet av Tschicholds gamle våpenfeller som et svik. England ble regnet som den typografiske reaksjonens høyborg - der rådde tradisjonen og symmetrien. Hans gamle venn Kurt Schwitters fant grunn til å 
unnskylde ham i et brev til Nelly van Doesburg: «Tschichold er sliten og har mistet grepet. Derfor må han få arbeide en stund i 'gammel stil'» (Burke 2007:294, min oversettelse). «En stund» skulle vise seg å vare livet ut, Tschichold vendte aldri tilbake til Die neue Typographie, og knapt nok til asymmetrien.
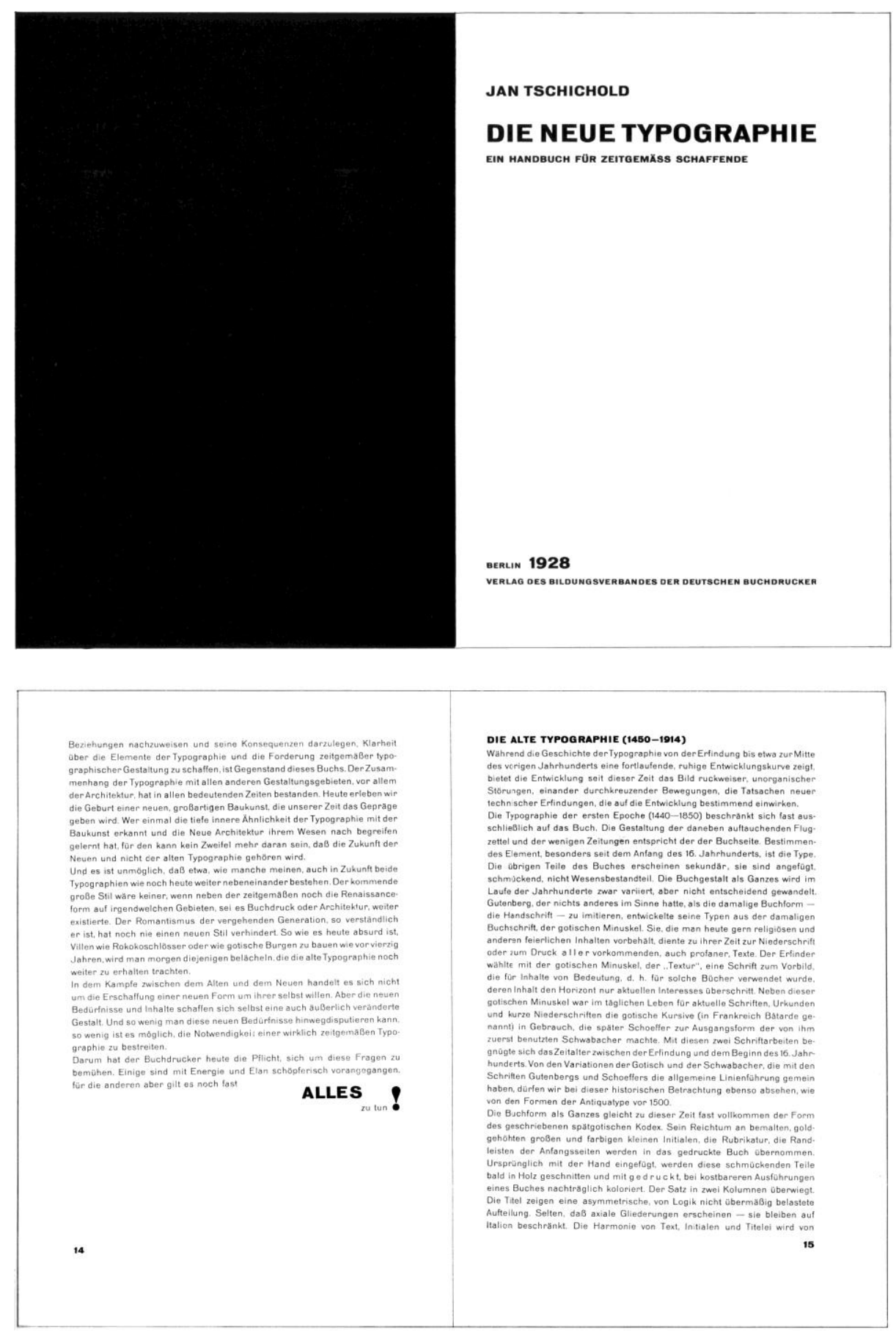

Klassikeren Die neue Typographie fra 1928 (McLean 1997:40-41). 


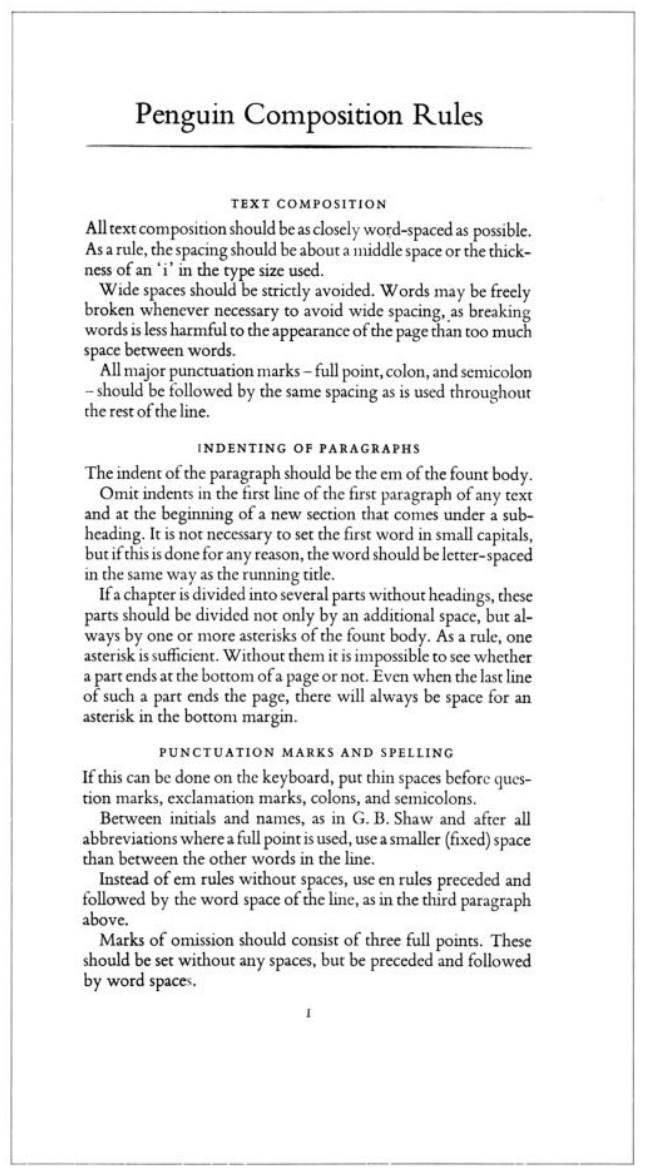

Da Tschichold kom til Penguin, oppdaget han at britiske trykkerier, slik han vurderte det, ikke behersket de mest elementære satsregler. Han utarbeidet da en 4-siders pamflett med regler for setting av Penguins bøker. Pamfletten er nå en klassiker, den er gjengitt i sin helhet i McLean 1997:80-81.
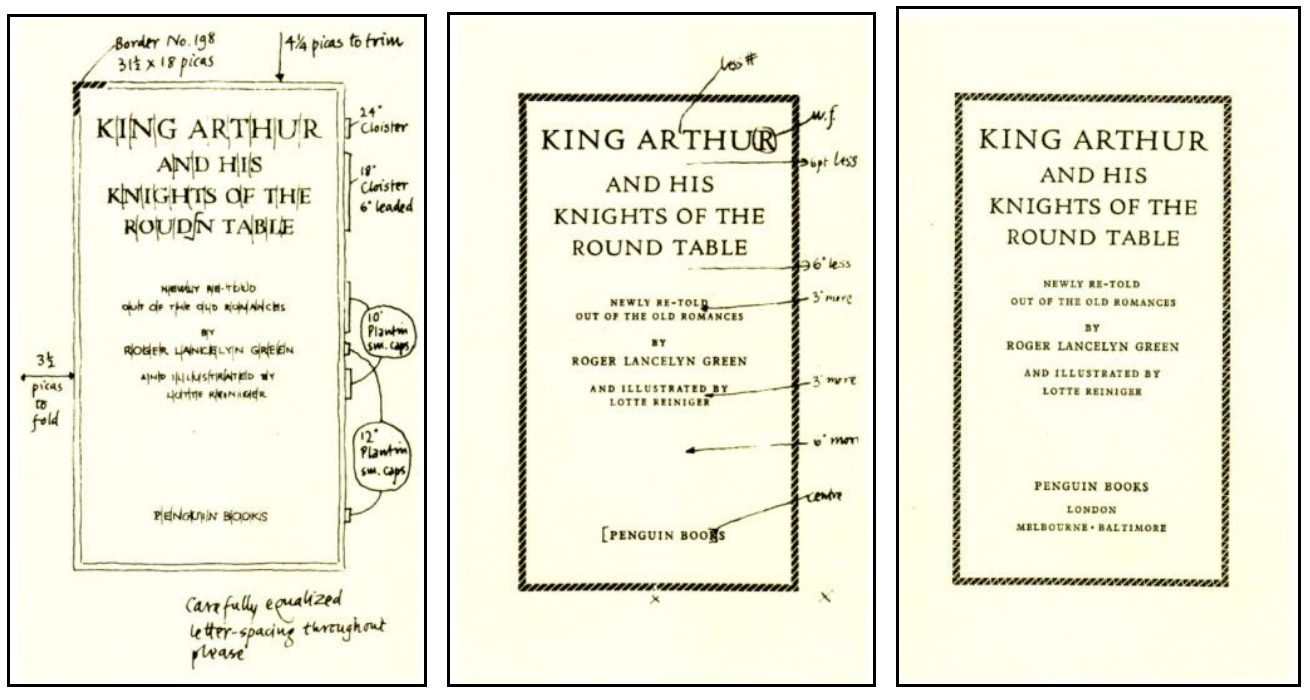

Arbeidet med tittelsiden til King Arthur and his Knights of the Round Table demonstrerer Jan Tschicholds typograf iske stil og nøyaktige arbeidsform. "One of the fussiest ...»

\section{Kritikken mot Tschichold}

Når en av grunnleggerne av Die neue Typographie gjør kuvending og så å si faller sine trosfeller i ryggen, måtte det skape reaksjoner. I en artikkel i Schweizer Graphische 
Mitteilungen $^{5}$ i april 1946, (side 193-200) under tittelen Über typografie går arkitekten og designeren Max Bill (Bill 2000) til angrep på Tschichold, riktignok uten å nevne hans navn han nøyer seg med å rette skytset mot «en av de kjente typografiteoretikerne» - men det har aldri vært tvil om hvem han sikter til. Max Bill var en av høvdingene innenfor den såkalte sveitserskolen. Sveitsertypografien er en retning i etterkrigstidens typografi som bygger mer eller mindre direkte på funksjonalismen og Die neue Typographie. Stilen fikk utvikle seg som en nasjonal typografisk stil under den sveits iske nøytraliteten under annen verdenskrig og ble frem til 1960-årene toneangivende i kraft av å være den eneste gjennomført helhetlige, moderne typografiske stilen. I Sveits var den nesten enerådende, og preget alle slags trykksaker. Den slo også an i en rekke europeiske land utenom Sveits; i Norge kom den på mote på begynnelsen av 1960-tallet og ble benyttet i både heldige og mer uheldige sammenhenger.

Stilen er - som Die neue Typographie - preget av et smalt skriftutvalg (grotesk), nøkternt skriftuttrykk og minimalistiske typografiske nyanser. Fokus er på flateinndeling og bruk av moduler (grid), foto og stilisert strek, men også på bevegelser og mønstre - som regel strenge! - som kan skapes gjennom kreativ lek med bokstavform. Det ideologiske grunnlaget er saklighet, produksjonsvennlighet og effektivitet. Typografiske detaljer og nyanser trer i bakgrunnen. Typiske kjennetegn er løs høyrekant - innrykk ved avsnitt blir ofret til beste for en stram venstre satskant - og titler i små grader. Man var opptatt av komposisjon, flatevirkning, gråtoner og proporsjoner. Groteskskriften Helvetica (lansert 1957) ble utvik let ut fra behovet for en groteskskrift som skapte tekstgrupper med en jevn, grå flatevirkning. Utover på 1970-tallet skulle sveitsertypografien møte kritikk, også fra egne rekker, for eksempel fra Wolfgang Weingart som hadde tilhold i Allgemeine Gewerbeschule i Basel, en av sveitsertypografiens bastioner: Den hadde stivnet, den var blitt dogmatisk og regelbundet og gav ingen kreativ frihet, det som Robin Kinross kaller «a situation of stagnation» (Kinross 1992:131).

Det er kanskje ikke tilfeldig at denne stilen ble utviklet nettopp i Sveits. Stilen er ren, nøktern og minimalistisk og slik sett kanskje i konformitet med sveitsernes bilde av seg selv: ærlige, sparsommelige, pragmatiske?

Tschicholds tilbakevenden til et mer tradisjonelt symmetrisk typografisk formuttrykk, og hans kritikk av den funksjonelle typografien, gjør ham i Bills øyne til en frafallen, nærmest en sviker, og han er tydelig både sint, skuffet og såret. Hans hovedargument mot Tschicholds kritikk mot Die neue Typographie er at den ikke er annerledes enn all annen kritikk mot kunstnerisk innovasjon og kreativitet: «Det er det samme argumentet som kunstnerisk innovasjon og kreativitet alltid blir møtt med.» (Bill 2000:62, min oversettelse.) Han hevder videre at denne typen argumenter kommer fra dalende stjerner som ser at «deres egen energi og tro på fremskrittet er for nedadgående og må søke tilbake til det sikre og velprøvede.» (Bill 2000:62, min oversettelse). Han er bekymret for den «tilbake-til-den gamle-typografienepidemien» (zurück-zum-alten-satzbild-seuche) - han betegner den til og med som en typografisk «heimatstil» ${ }^{6}$ - en stilart som ser ut til å gripe om seg på andre områder, og han spør seg hvorfor. Hans s var er at typografien er en kunstform som lett henfaller til regler, og hvis man ikke passer på, kan friheten og kreativiteten bli erstattet av rigiditet og reaksjon. «Enhver tese som fremmes, ... bærer i seg faren for å stivne og dermed bli et hinder for utviklingen»(Bill 2000:64, min oversettelse). Bill hevder videre at Die neue Typographie representerer utvikling og frihet, en arena for kreativitet; den tradisjonelle er reaksjonær og regelbundet og uten mulighet for kreativ utfoldelse. Friheten krever kompetanse og talent; uten talentet må man støtte seg på reglene. «Det uholdbare ved det gamle skjemaet er blitt endelig og avgjørende demonstrert,» sier han (Bill 2000:64, min oversettelse), men unnlater å si hva det er ved det gamle skjemaet som gjør det uholdbart og hvordan dette er blitt demonstrert. Men ut fra Bills generelle argumentasjon kan vi gjette: Den tradisjonelle 
typografien er uholdbar fordi den ikke gir utviklingsmuligheter - den er stivnet, den er en tvangstrøye og ingen arena for kreative talenter.
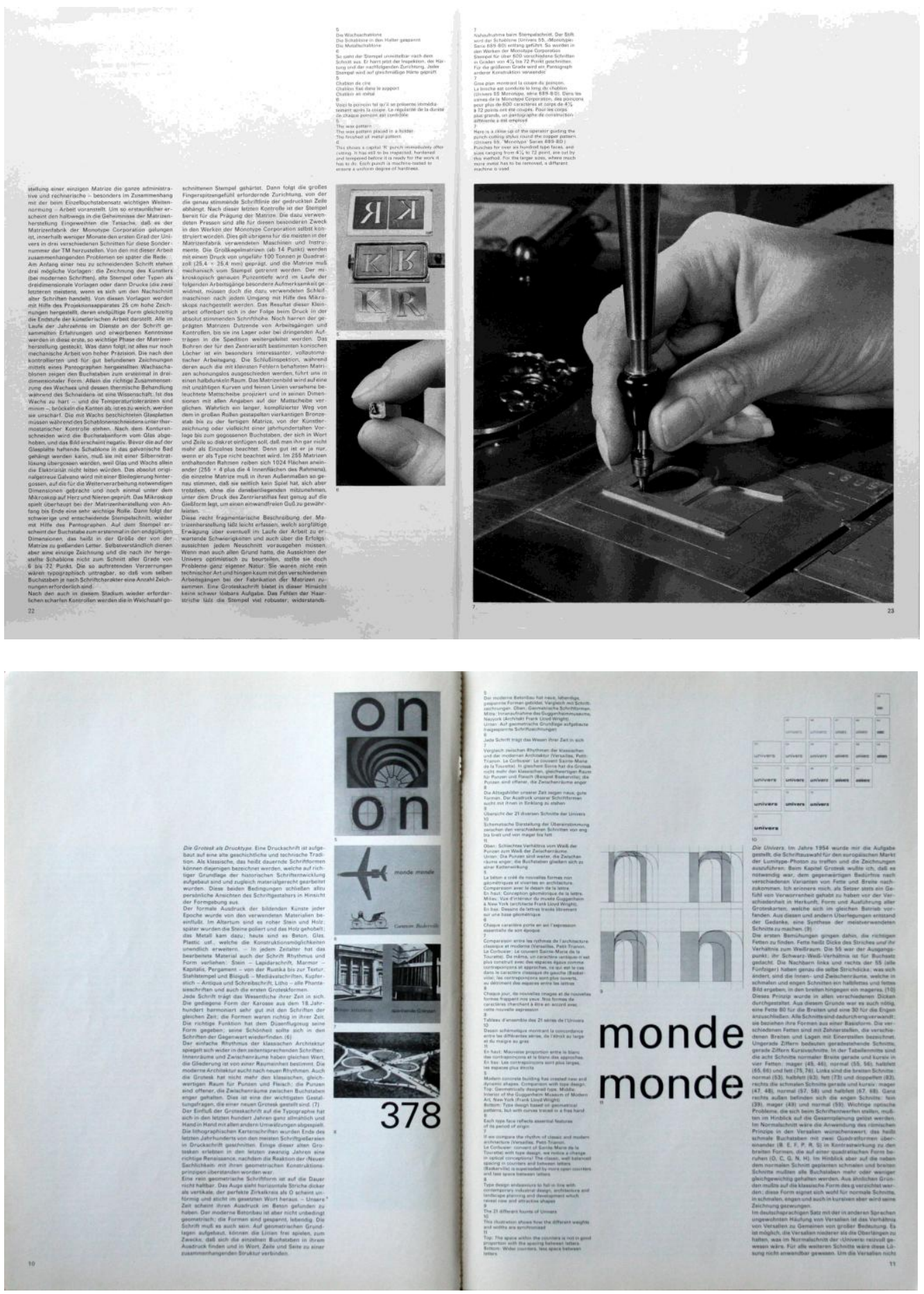

To oppslag fra Typografische Monatsblätter januar 1961. Tette, rektangulære tekstspalter uten innrykk ved avsnitt, store åpne flater; tekst og bildeflater har i utgangspunktet samme form og skaper en streng oppdeling, men flatene brytes, og løs høyrekant i bildeteksten myker opp inntrykket. Typografische Monatsblätter (TM) er kanskje mer enn noe annet organ utstillingsvindu for sveitsisk typografi. Bladet er sammenslått med det tidligere Schweizer Graphische Mitteilungen (SGM), og det var i dette tidsskriftet Max Bill og Jan Tschichold førte sin debatt. 

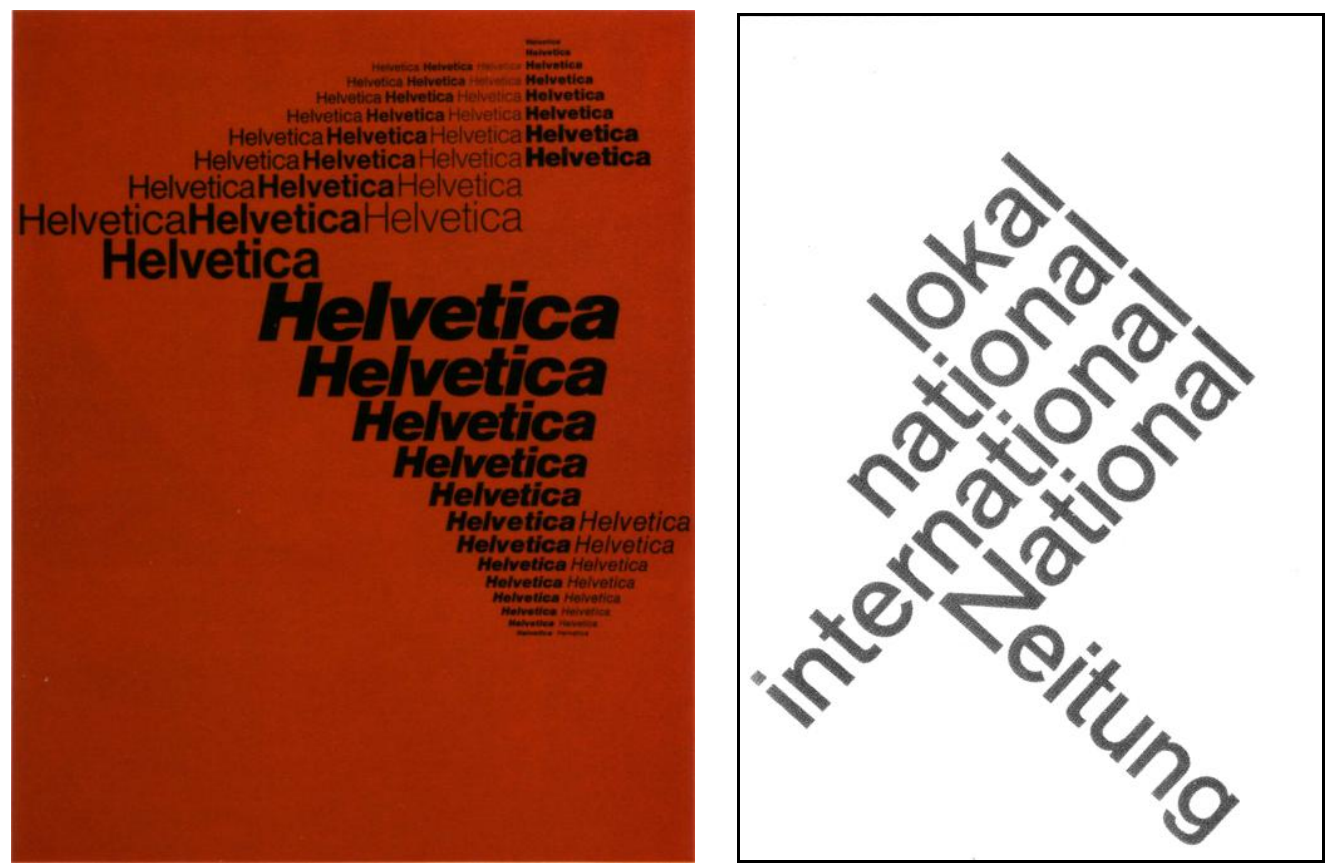

Sveitsertypografien som typografisk stil kan være tekst- og bokstavfokusert. Designet tar utgangspunkt i tekstens eller bokstavens form og utvikler mønstre, linjer, bevegelser. Lekent, men mønstrene er som regel strenge og rigorøse. Til venstre, forsiden til en salgsbrosjyre for skriff amilien Helvetica fra begynnelsen av 1960-tallet. Sveitsergrotesken Helvetica oppnådde i løpet av 1960-årene en voldsom popularitet over store deler av verden. Til høyre en plakat laget av Karl Gerstner for Baselavisen National Zeitung i 1960.

Han setter for eksempel opp noen kriterier for funksjonell typografi: Først og fremst, sier han (Bill 2000:67) at man må ta hensyn til språket og lesingen; deretter kan det bli åpning for det estetiske. Et fullt utvik let tekstbilde skal både gi støtte for det lesende $\varnothing$ ye og for typografiskestetiske krav. Det er først da at man kan snakke om funksjonell typografi, mener han. På hvilken måte dette kravet ikke møtes i tradisjonell typografi er han mer uklar på, men hevder at den tradisjonelle typografien er uanvendelig først og fremst fordi den er unødig dekorativ og derfor tidsmessig upassende. Teksten skal designes slik at den blir en levende tekstorganisme. Med det mener han antagelig at de enkelte elementene må fylle sin funksjon og stå i et slikt forhold til hverandre at de fremstår som en helhet.

Det slår meg at Bills argumentasjon og hans definisjon av funksjonell typografi er formet i så runde og diffuse vendinger at de kan anvendes på hva som helst. De kunne like gjerne tas til inntekt for den tradisjonelle typografien. For dette er faktisk formuleringer som Tschichold også kunne ha brukt. Bill setter den tradisjonelle typografiens krav om at den typografiske stilen må tilpasses teksten og innholdet helt på spissen når han sier bøker må produseres i den aktuelle tidens stil: Goethe og Schiller kan vi sagtens klare, men hva med Platon og Konfusius? spør Bill (2000:69) Tschicholds løsning - som han gir et par eksempler på - er å skape en mest mulig nøytral form, og iallfall ikke plage gamle tekster med våre tiders motesvingninger (Tschichold 2000:78-82).

Det er kanskje viktig å presisere at også Bill markerer en slags avstand til Die neue Typographie. Han innser at 30-tallets typografiske stil var plaget av «karakteristiske, motepregete elementer: tykke streker, store rundinger, overdimensjonerte sidetall og lignende»(Bill 2000:68, min oversettelse). Sveitserstilen, som han kaller «funksjonell», bygger riktignok på Die neue Typographie, men har fridd seg fra slike innslag. (Bill 2000:68.) 
Jeg vil her henvise til en liten, men morsom detalj, som kan eksemplifiseres slik:

bill praktiserer «kleinschreibung»! det er noe som går tilbake til walter porstmanns revolusjonære idé fra 1920 om å avskaffe alle store bokstaver. ideen er i slekt med taylors $^{7}$ teorier om industriell produksjon: effektivt, rasjonelt og $\varnothing$ konomisk. (kinross 2002a:137.) herbert bayer ${ }^{8}$ var en av dem som mente at både en stor og en liten bokstav ikke er nødvendig for å uttrykke en og samme lyd, og avskaffet store bokstaver i bauhausskolens trykksaker og korrespondanse. hele artikkelteksten til bill er satt kun med små bokstaver, kanskje et eksempel på hvordan man i stridens hete og $\mathrm{i}$ rendyrkingen av prinsippene kommer i skade for å bytte bort nettopp den funksjonaliteten som stod som motto for det hele. det er virkelig litt vrient å lese en tekst som ikke markerer ny setning med stor forbokstav. på tysk er det enda mer uvant også å måtte unnvære store forbokstaver i alle substantiv.

\section{Hva er ty pografi?}

Bills krav om et kreativt rom i typografien rører ved et sentralt punkt i spørsmålet om hva typografi og grafisk design er. Men da vil jeg først rydde opp litt i begrepene.

I Norge har begrepet typografi vært tett knyttet til håndverksfaget typografi. En typograf var $^{9}$ en som utførte sats- og ombrekningsarbeid, og som hadde en del elementære, nokså regelbaserte og rigide kunnskaper om utforming av tekst og tekstsider. Innenfor denne konteksten ble typografien et stillestående fagområde uten særlig spørsmål og debatt, og som kunstnere og grafiske designere vendte ryggen nettopp fordi den som arena var uten utfoldelsesmuligheter (Rannem 2005:11-12).

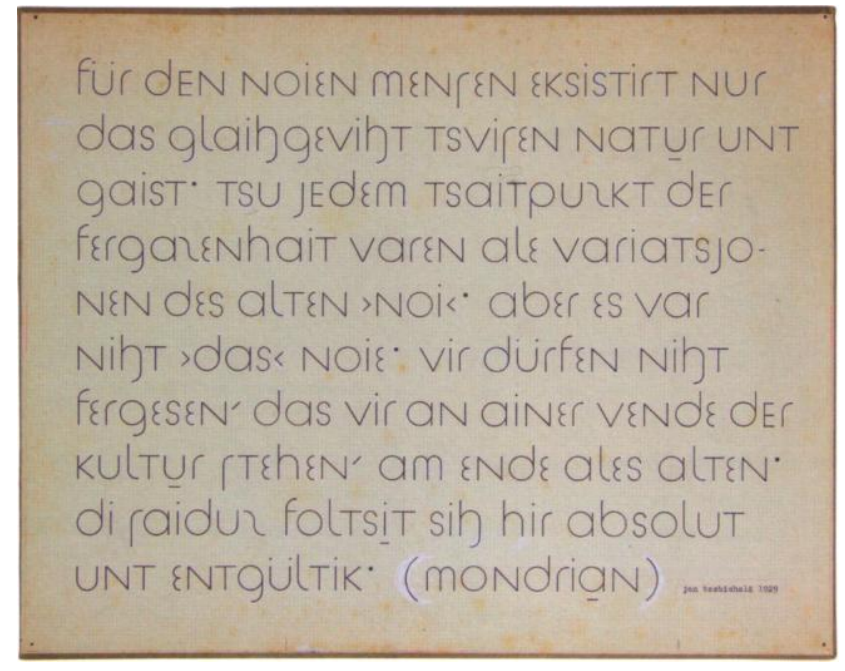

Også Jan Tschichold var som ung opptatt av forenkling og «av-ornamentering» av skiften. Her er hans design for en monoalfabetisk skrift. Jakten på det effektive, det rasjonelle, og kanskje det naturlige, får ham til å våge seg utenfor sin kjernekompetanse: Han foreslår en ny og mer «bokstavelig» ortografi. Illustrasjonen er laget til en artikkel i Typographische Mitteilungen mars 1930 (Burke 2007:156).

I England og på kontinentet har derimot begrepet helt fra tidlig på 1900-tallet vært knyttet til tilretteleggings- og designprosessen (Kinross 1992:55). Faget engasjerte designere, arkitekter, kunstnere og forlagsfolk; det ble intellektualisert, og både det progressive Tyskland og det tradisjonsbund ne England strevde med spørsmål som: Er typografi kunst? Hva er typografiens hensikt og funksjon? - og gav stikk motsatte svar: Tyskerne skapte en ny stil med nye formbegreper - die neue Typografie - mens engelskmennene prøvde å raffinere og rendyrke 
den tradisjonelle symmetrien. Dette viser at typografifaget ikke var hugget i sten, men at det var behov for problematisering og debatt.

Typografi og typografisk design handler primært om tilrettelegging av tekst, alene eller i kombinasjon med bilder og andre elementer. I den forstand er den underlagt noen funksjonelle krav; ett av dem er leselighet. Men en skal ikke ha arbeidet lenge med typografi før en oppdager at dette er en høyst relativ faktor. Kravet til leselighet må nødvendigvis bli ulikt i en roman og en telefonkatalog eller en oppslagsbok, simpelthen fordi de brukes og leses på forskjellig måte, men også av hensyn til produksjon, oppbevaring, kostnad osv. Linjelengden i en avis ligger godt under kravet til det optimalt leselige, men gir til gjengjeld større muligheter til å skape et ryddig helhetsinntrykk i kombinasjon med bilder og andre elementer. Plakater og annonser skal fange oppmerksomheten, ofte på litt avstand, men inneholder også tekst for en mer normal lesemodus.

I dag har digitalteknologien opphevet det produksjonsmessige skillet mellom typografi og grafisk design, og det er ikke lenger så interessant å definere hva som er hva. For typografen, som for designeren, er det et slags imperativ å få den typografiske formen til å spille sammen med budskapet og lage en passende formmessig ramme for tekst og innhold. Nå ser vi det som en selvfølge at her må det være store rom for uttrykk.

Er typografen kun en nøytral formidler av andres budskap til en tredje part? Eller er han en aktiv medspiller - with a licence to communicate Kan han, på kunstnerens vis, gi sin egen tolkning av budskapet på toppen av tekstens innhold og form, eller må han lojalt underkaste seg en avsenders og en målgruppes behov og betingelser?

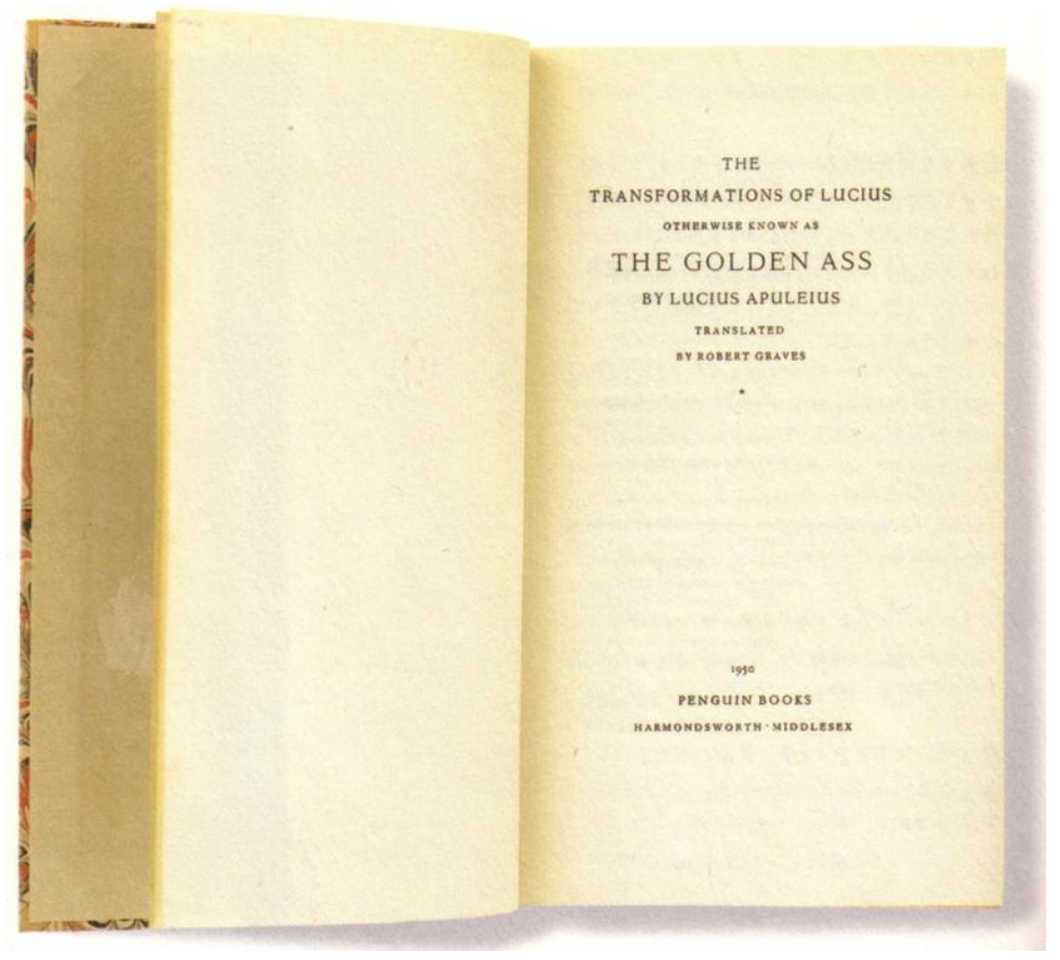

Tradisjonell, ja - men nøytral? (Doubleday:118.)

Svaret er etter min mening: begge deler. Ingen form er nøytral, verken en tekstlig eller en typografisk-visuell. Man kan få noe til å se objektivt ut, men det er noe annet. Uansett hvor objektiv en typograf prøver å være, vil det typografiske produktet være hans løsning, og være en av mange mulige typografiske løsninger, altså en av flere tolkninger av budskapet. 


\section{Tschicholds svar}

Tschichold (2000) svarte på kritikken i Bills artikkel i 1946 (2000) i en personlig og noe følelsesladet artikkel i samme tidsskrift i juni samme år - han var fremdeles i S veits - under tittelen Tro og virkelighet (Glaube und Wirklichkeit). Her forklarer han omstendighetene rundt Die neue Typographie; hvorfor den måtte komme, hvorfor den ble som den ble og hvorfor han måtte vende den ryggen. Som bakgrunn for Die neue Typographie trekker Tschichold frem den sørgelige tilstand han mener tysk, sveitsisk og annen europeisk typografi befant seg i rundt 1920 - trykksakene var invadert av «et utall skriftsnitt som i dag er utenkelige, og var uten regler for orden og ryddighet.» (Tschichold 2000:72.) Tschichold, og han må nok dele æren med flere, så behovet for en opprydding, og søkte mot forenkling. De estetiske modellene fant de $\mathrm{i}$ industriproduktene, og de erklærte grotesk som det (eneste) moderne skriftsnitt fordi det var det enkleste (les: reneste) - men så legger han til: «noe som viste seg å være feil». (Tschichold 2000:73). Symmetrien ble forkastet til fordel for asymmetrien - men i den forbindelse føyer han til noe interessant: «(Symmetrien) hadde neppe noen gang vært anvendt på en fornuftig og forståelig måte» (Tschichold 2000 :73). Han mente altså at symmetrien ble forkastet på gale premisser: ikke fordi den i og for seg var ubrukelig, men fordi den var blitt anvendt uten typografisk innsikt. Die neue Typographie kan dermed kanskje mer sees som et opprør mot dårlig typografi. Men symmetrien fikk skylda og ble kastet på dør. Å følge gode og fornuftige regler for sats og boktypografi er ikke å skru klokken tilbake, sier han. Derimot er en eksentrisk typografisk stil nesten alltid diskuterbar (Tschichold 2000:78).
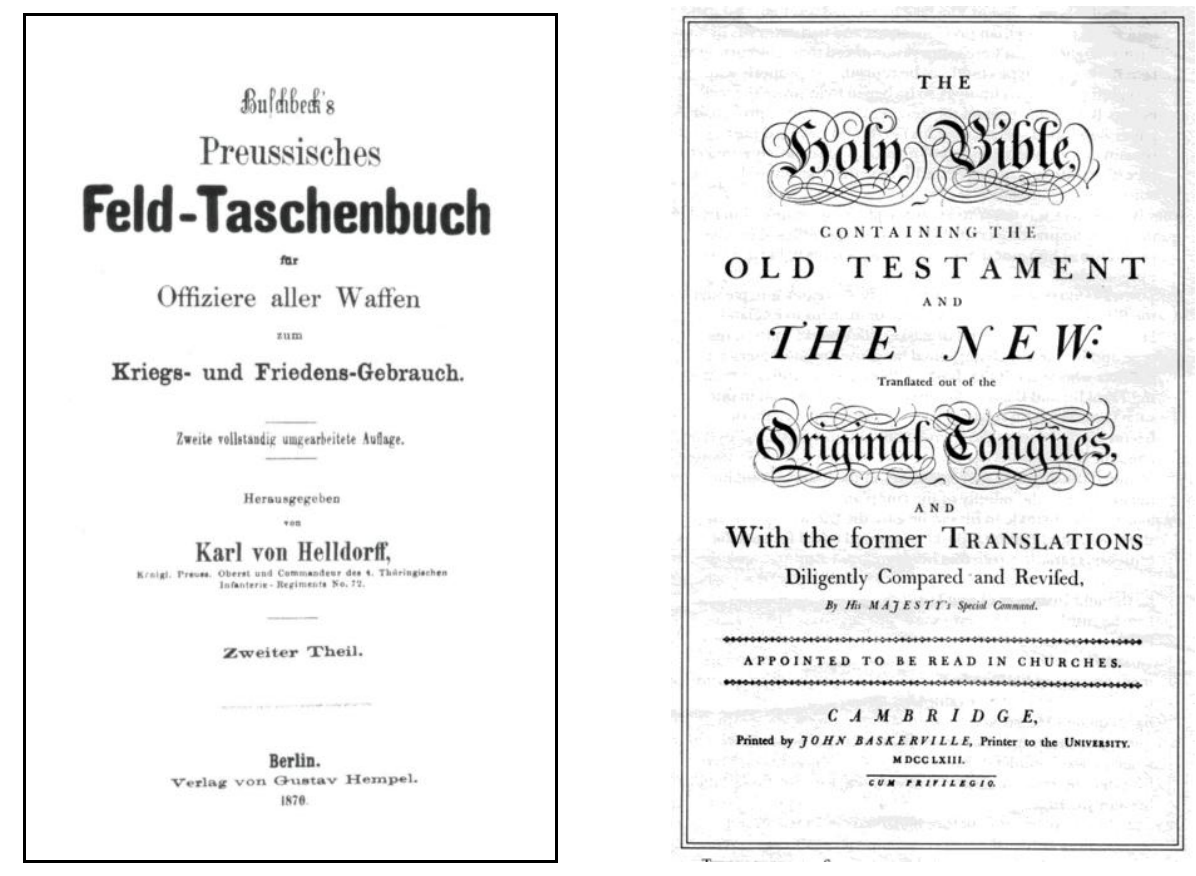

Symmetrien «hadde neppe noen gang vært anvendt på en fornuftig og forståelig måte» (Tschichold 2000:73). Tittelsiden til venstre er fra 1870 og illustrerer historismens hang til å blande sammen mange ulike stilelementer og stilarter. Som nevnt tidligere - symmetrien makter å holde dette sammen i et slags grep, men det utbroderte og komplekse uttrykket ble gjenstand for funksjonalistenes kritikk. Tittelsiden til John Baskervilles bibel fra 1763 ble vel rimeligvis også rammet av den samme kritikken.

Den historiske verdien av denne prosessen, sier han (Tschichold 2000:73), var en rensing av typografien for døde elementer, innføring av fotografiet og en modernisering av typografiske regler. Jeg vil og legge til: innføring av nye. Men han tilføyer: «Tra gedien var at den asketiske 
enkelheten, snart nådde et punkt der videre utvikling var umulig» (Tschichold 2000:73, min oversettelse og min kommentar), en asketisk enkelhet som øyensynlig var en nødvendig del av renselsesprosessen Tschichold tar altså Bills argument om den tradisjonelle typografiens regelbund ne rigiditet og stivnethet og vender det mot ham selv og mot den nye typografien, den ser ut til å ha malt seg inn i et hjørne.

Den nye typografien egner seg godt til reklame for industriprodukter, sier Tschichold, «... de springer ut av det samme» (Tschichold 2000:74, min oversettelse). Men uttrykksmulighetene er begrensede, fortsetter han, «fordi den kun etterstreber renhet og klarhet». Det Tschichold sneier innom her, i en enslig setning, er et kjernespørsmål i forståelsen av den nye typografien, så vel som av hele denne debatten og typografien generelt. Det han så vidt jeg forstår etterspør, er et større register av formuttrykk - muligheten til å forme teksten etter innholdet. Denne ene setningen ... uttrykksmulighetene er begrensede og så videre, forteller at Tschichold er på sporet av noe som på denne tiden bare så vidt var kommet på den typografiske agenda. Det er typografiens mulighet til å skape uttrykk, følelsesmessige assosiasjoner - til å bruke skrift, komposisjon og andre stiluttrykk til å formidle et visuelt budskap, et metabudskap på toppen av det tekstlige innholdet. Det er dette som dagens typografer og grafiske designere kaller identitet. Tschichold var nok blant de første som innså denne sammenhengen.

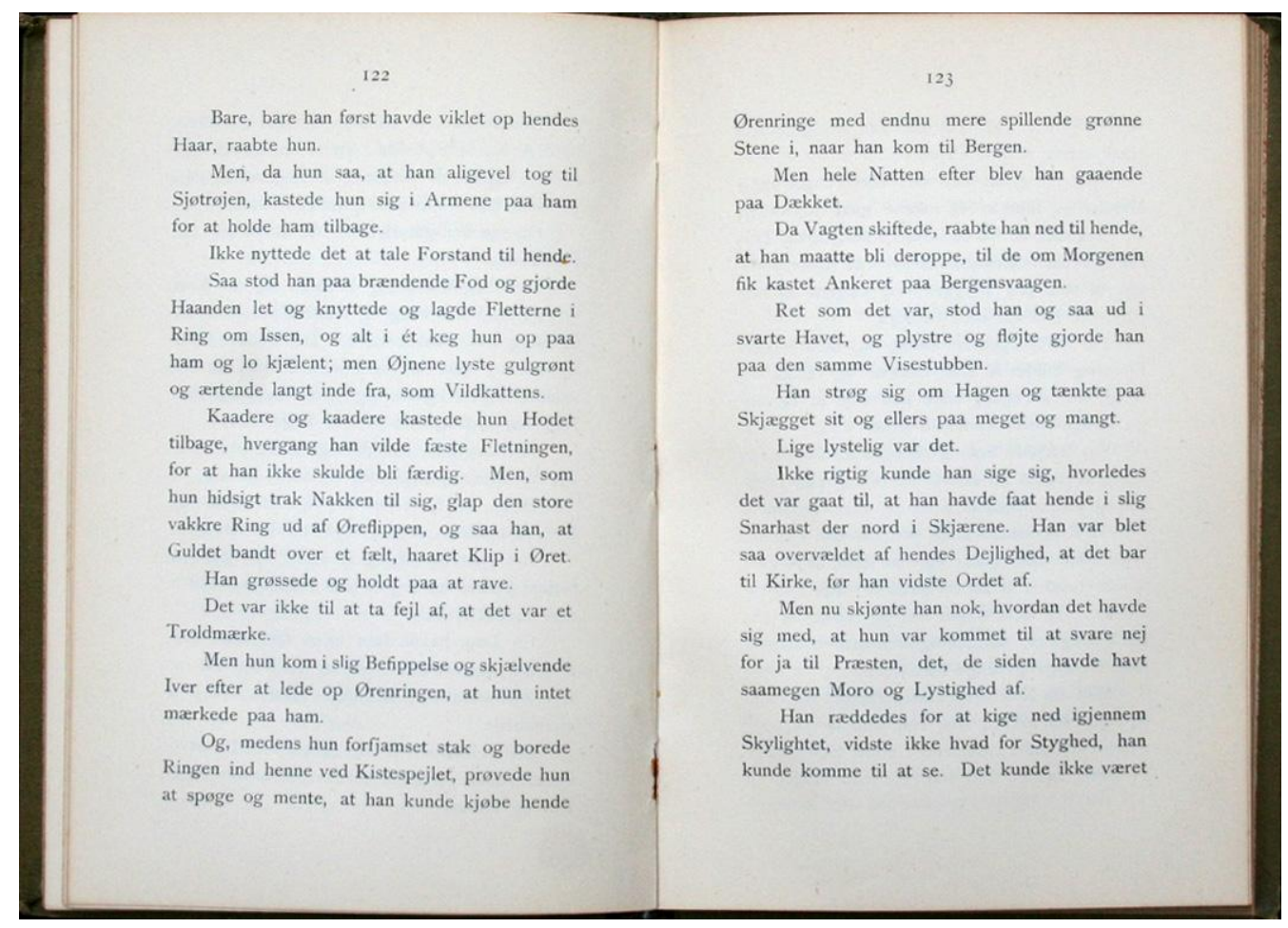

Jan Tschichold gikk til felts mot den elendige kvaliteten i boktypografien - dårlig skriftdesign, slappe proporsjoner i margfordelingen og altfor stor linjeavstand, noe Jonas Lies Trold fra 1892 er et av et utall norske eksempler på. Han for etok i årene etter krigen en del undersøkelser av manuskripter og trykk fra middelalderen og renessansen, og i 1961 publiserte han en serie klassiske kanoner for sidekomposisjon basert på det han kaller «ikke-vilkårlige proporsjoner», dvs. formater og satsspeil med velkjente og anerkjente proporsjoner som hviler på rene eller matematisk interessante talfforhold. (Tschichold 1960)

Vi kan også spekulere på om ikke det er slik at Tschichold, ytterst detaljfokusert og pedantisk som han var, innerst inne hadde større affinitet til den harmoniske og stillfarne symmetrien enn til den dynamiske og mer «støyende» neue Typographie. God symmetrisk typografi er ekstremt avhengig av at alt stemmer ned til minste detalj, noe som sikkert passet Tschichold bra. 


\section{Ideologi?}

Den kanskje mest interessante observasjonen man kan gjøre ut fra denne meningsutvekslingen, er den manglende erkjennelsen av typografien som aktivt visuelt uttrykksmiddel. Tschichold erkjenner at teksten må passe til innholdet, og han er opptatt av at (bok)typografien ikke må distrahere leseren; Bill er opptatt av at typografien må gjenspeile tidsånden. Begge går etter min mening i den fellen at de mener å ha funnet et slags endelig svar.

Dette ser jeg på som ideologi. Den funksjonelle typografien var - som typografi betraktet - kanskje mer funksjonell for avsenderen enn for mottakeren. Den var ikke det endelige svaret på en funksjonell typografi - kanskje ikke engang sin egen tids svar. Men den var sin egen tids uttrykk. Eller rettere sagt uttrykket til tidens ledende ut $\varnothing$ vere og ideologer. Det sier noe om at typografi også er et slags språk, et visuelt metaspråk som gjør designeren til en mer eller mindre aktiv medkommunikatør. Objektiv eller nøytral typografi er en illusjon - den kan gi inntrykk av å være nøytral, men det er noe annet.

For Max Bill og andre innenfor sveitserskolen var det nok tungt å svelge at den nye typografien ble henvist til «reklame og aksidens». Hele poenget med den nye typografien var jo nettopp at den ikke var knyttet til produkt, men til tid - det de nye typografene kalte «en typografi for vår tid». Den typografiske stilen stod over produktet og innholdet. Den var «objektiv» fordi den var i pakt med, og gled sømløst inn i, sin tidsalder. (Et ord som ofte går igjen, er Zeitgeist.)

De nye typografene gjorde etter min mening en fatal feilslutning. I sin begeistring over å ha brutt ut av symmetriens og antikvaens tvangstrøye gikk de ut fra at den nye typografiske stilen var en form for «fremskritt» [progress] som gjorde alt tidligere bakstreversk og passé. De koblet den nye stilen til «den nye tid»-industrisamfunnet - og fant en logisk overensstemmelse som ble en begrunnelse for funksjonaliteten. De sluttet ganske enkelt at en typografi for «vår tid» måtte passe for alt i den nye tid. Den nye typografien var prinsipiell og teoretisk og hadde form av kategoriske imperativer.

\section{Syntese}

Etter disse artiklene i Typographische Monatsblätter fra 1946 stoppet imidlertid diskusjonen om Die neue Typographie . Bortsett fra at Tschicholds tidligere nære kollega, Paul Renner, prøvde å roe gemyttene i en senere artikkel, men det var først i 1948. Han kaller Bauhaus en «stasjon på veien mot vår tids stil» (Renner 2000:89), på samme måte som arts and crafts og jugend. Renner setter de historiske stilskiftene inn i en dialektisk sammenheng der nye stiloppfatninger er en reaksjon på tidligere. Han tilbakeviser påstanden om at Tschichold gikk fra det ene ytterpunkt til det andre, fra det moderne til det reaksjonære; tvert imot søkte Tschichold den dialektiske middelveien, sier Renner. Tschichold vendte ikke tilbake til den tidligere tradisjonelle typografien, han fant en slags syntese, hevder han.

Med utgangspunkt i korrespondanse mellom Renner og Tschichold i forkant av Renners artikkel, finner Burke (1998:176) grunn til å hevde at Renner oppfattet Tschicholds syntese som «moderne», ikke i betydningen avant garde, men i betydningen tidsmessig (contemporary). Dessverre er en middelvei nå ofte oppfattet som noe middelmådig, sier Renner, mens den i antikken var «den gyldne». Men «... middelveien har, uansett, mer energi i seg enn den ensidig ekstremisme; den er det fruktbare stormens $\varnothing$ ye i en dialektisk prosess ... ». Renner spør kontrafaktisk hvor typografien ville tatt veien om ikke den nye typografien var blitt stoppet av nazistene i 1933. Jeg vil hevde at han mer enn antyder at svaret ligger i dialektikkens lovmessighet. 


\section{Die neue Typographie i retrospekt}

Det er ikke vanskelig å tenke seg at «oppdagelsen»av asymmetriens muligheter i typografi og grafisk design må ha skapt begeistring og entusiasme og en følelse av frihet, et modig skritt ut $i$ åpent lende. Die neue Typographie var noe nytt som skilte seg radikalt fra det folk var vant til. Den var - i kraftig motsetning til den tradisjonelle hverdagsstypografien på den tiden stilren og konsistent, og den var spektakulær og lett gjenkjennelig. Den viste vei ut i et nytt område med frihet til å eksperimentere. Det er lett å skjønne at Bill ser dette som en arena for kreativ utfoldelse. Mange av de førende aktørene som er nevnt tidligere var altså fremtredende kunstnere og designere som skapte design på et høyt nivå. Det må ha vært lett å bli grepet av dette nye, enkle - og komme til å tro at det var løsningen på alt. Den ble dogmatisk.

Men det de nye typografene kanskje ikke så, var at det i og for seg enkle, geniale og universelle formgrepet - asymmetrien - var satt inn i en situasjonsbetinget, stilistisk ramme som ikke tillot videre eksperimentering. Asymmetrien ble dermed assosiert med Die neue Typographie - i meningsutvekslingen mellom Bill og Tschichold er de to nærmest synonyme. Men de nye typografene hadde gjort en stor oppdagelse. Det skulle vise seg at asymmetrien som formprinsipp kanskje hadde sitt største potensiale utenfor funksjonalismens og sveitserskolens strenge rammer. «Die neue Typographie innførte radikalt nye begreper $\mathrm{i}$ hele forestillingen om grafisk formgivning», sier John Lewis (1970:121), og fortsetter: «Den virket som en renselsesprosess og skjenket oss et helt nytt formspråk når det gjelder å angripe tusenvis av nye designproblemer der det ikke fantes forbilder.»

Jeg finner det interessant å se hvordan to debattantene, med det samme faglige mål, kan ende i opposisjon til hverandre. Bill og funksjonalistene mente at de hadde funnet en formmessig nøkkel som var i pakt med tiden, og som derfor hadde en slags - riktignok tidsbetinget - nøytralitet og kanskje også noe objektivitet over seg. Det var en typografisk form som skulle vise den moderne leser veien inn til budskapet uten distraherende omveier. Tschichold - og for den saks skyld også de britiske tradisjonalistene - var også på jakt etter det nøytrale og objektive, det funksjonelle, det som ikke distraherer leseren. Warde kalte det «gjennomsiktighet»(1970:24). Det kan heller ikke være tvil om at Tschichold, blant annet gjennom sitt nådeløse krav til kvalitet i minste detalj, leverte et sterkt bidrag til rehabilitering og opprusting av den tradisjonelle typografien. Han viste at det ikke var symmetrien som formprinsipp det var noe i veien med, det var måten den ble anvendt på. Etter å ha vært førende i utviklingen av den nye typografien, ble Tschichold en av dem som også fornyet den tradisjonelle typografien og gjorde den mer funksjonell og estetisk tiltalende.

\section{Øyvin Rannem}

Typograf, førstelektor ved Studiet for visuell kommunikasjon, Høgskolen i Buskerud Redaktør for www.typografi.no

E-mail: oy vin@rannem.no

\section{Referanser}

Bill, Max (2000) On typography. I Typography papers 4. London: Hyphen Press [Bill, Max (1946) Über Typographie. I Schweizer Graphische Mitteilungen. 65(4), 193-200].

Burke, Christopher (1998) Paul Renner. The art of typography. London: Hyphen Press.

Burke, Christopher (2007) Active literature. Jan Tschichold and New Typography. London: Hyphen Press.

Doubleday, Richard B. (2007) Jan Tschichold at Penguin. A resurgence of clas sical book design. I Idea (3), 99142.

Eng, Torbjørn (1998) Den nye typografiens gjennombrudd i Norge 1-3, Norsk Grafia (2-4).

Kinross, Robin (1992): Modern typography. An es say in critical history. Hyphen Press.

Kinross, Robin (2002a): Large and small letters. Authority and democracy. I Kinross, Robin Unjustified texts. Perspectives on typography. London: Hyphen Press.

Kinross, Robin (2002b): Jan Tschichold. I Kinross, Robin Unjustified texts. Perspectives on typography. London: Hyphen Press. 
Lewis, John (1970) Anatomy of Printing: The Influences of Art and History on its Design. London: Faber. McLean, Ruari (1997) Jan Tschichold. A life in typography. London: Lund Hu mphries.

Michl, Jan: Form Follows WHAT? The modern ist notion of function as a carte blanche. http://www.geocities.co m/Athens/2360/jm-eng.fff-hai.html

Rannem, Øyvin (2005) Typografi og skrift. Oslo: Abstrakt.

Renner, Paul (2000) On modern typography. Typography papers 4, London: Hyphen Press. [Renner, Paul (1948) Über moderne Typographie. I Schweizer Graphische Mitteilungen. 67 (3), 119-120]

Ruder, Emil (1967) Typographie. Teufen: Niggli.

Smith, Frank (1994) Understanding reading. A Psycholinguistic Analysis of Reading and Learning to Read. Hills dale NJ: Lawrence Erlbaum Associates.

Spencer, Herbert (2004) Pioneers of modern typography. Aldershot: Lund Hu mphries.

Tschichold, Jan (1962) Willkürfreie Massverheltnisse der Buchseite und des Satzspiegels. Basel: Bucherer, Kurrus \& Co. (Norsk oversettelse i Sartrykk av Norsk Faktortidende, desember 1963).

Tschichold, Jan (1928): Die neue Typographie. Ein Handbuch für zeitgemäß Schaffende. Verlag des Bildungsverbandes der Deutschen Buchdrucker, Berlin 1928. Engelsk utgave: The new typography. A handbook for modern designers. 1995.

Tschichold, Jan (1960): Erfreuliche Druchsachen durch gute Typographie. Svensk utgave: Ändamålsenliga och vackra tryksaker genom god typografi. Bonniers 1965.

Tschichold, Jan (2000): Belief and reality. I Typography papers 4. [Tschichold, Jan (1946) Glaube und Wirklichke it. I Schweizer Graphische Mitteilungen. 65(6) 233-242].

Warde, Beatrice (1970) The Crystal Goblet. An address to the Brit ish Typographers' Gu ild at the St. Bride Institute, London 1932. I The Monotype Recorder, 44(1), 24-?.

Yamamoto, Taro (2007) Considering the Dispute between Jan Tschichold and Max Bill. I Idea (3), 182-188.

1 Aksidens: småtrykksaker, også kalt leilighetstrykksaker, for eksempel privattrykksaker, brevark og konvolutter, plakater, brosjy rer, invitasjoner, adresser osv.

2 Eksempler er Arial, Frutiger, Gill, Helvetica, Futura osv. Av disse er det strengt tatt bare Futura som hører hjemme innenfor rammen av Die neue Ty pographie. Arial og Helvetica hører hjemme i etterkrigstidens sveitserstil, mens Frutiger og Gill er såkalt humanistisk pregede grotesker.

3 Paul Renner (1878-1956), kunstmaler, ty pograf og typografiteoretiker, skriftdesigner. Paul Renner stod bak skriftsnittet Futura. For flere opply sninger om Renner, se Christopher Burkes biografi Paul Renner. The art of typography. London: Hyphen Press 1998.

4 Gleichschaltung - ensretting - ordet er en nazistisk oppfinnelse som betegner partiets strategi for å skape enhet mellom parti og stat. Goebbels’ Propagandamin isterium øvde streng kontroll med kunsten og kulturlivet for å hindre folk i å komme i kontakt med opposisjonelle tanker. De slo spesielt ned på moderne og progressive former for kunst, som ble stemplet som «entartet», dvs. dekadent eller degenerert. Paul Renner var en av dem som på et tidlig tidspunkt så dette komme. I 1932 skrev han sitt berømte kritiske essay Kulturbolschewismus? (Som han forresten måtte til Sveits for å finne forlegger til.) Etter at Hitler var kommet til makten i 1933, ble han arrestert. Pamfletten er senere kommet i fotografisk opptrykk på Stroemfeld Verlag, Frankfurt am Main og Basel 2003.

5 Månedsskrift for Das graphische Kunstgewerbe

6 Nasjonalistisk 1900-tallsbevegelse innenfor arkitektur og interiør som ville fremme regionale og «innfødte» stiltradisjoner; særlig intens i Sv eits, Ty skland, Polen og Finland. I Sveits var stilen assosiert med anerkjente «sveitsiske» verdier som beskjedenhet, ærlighet og samhørighet med naturen. Stilen var i opposisjon til 1930-tallets moderne funksjonalisme med sin tilknytning til industrisamfunnet og sine kosmopolitiske overtoner Forfatter ????

7 Frederic Winslow Taylor (1856-1915) - kjent for sine metodiske studier av arbeidsprosesser med tanke på å øke effektiviteten i arbeidslivet. Regnes som opphavsmann til scientific management.

8 Herbert Bayer - typograf, designer, maler og fotograf, er mest kjent som lærer i typografi og reklame ved Bauhaus i Dessau. Han laget også skolens læremateriell.

9 Typografien forsvant som eget yrkesområde, og typograf som yrkestittel, i kjølvannet av IT-revolusjonen på 1980-tallet da faget ble integrert i et større førtry kksområde sammen med bildebehandling. Dagens yrkestittel er «mediegrafiker». 